\title{
Allozyme assessment of genetic diversity within the relic Sicilian fir Abies nebrodensis (Lojac.) Mattei
}

\author{
Fulvio Ducci ${ }^{\mathrm{a}}$, Roberta Proietti ${ }^{\mathrm{a}}$, Jean-Michel Favre ${ }^{\mathrm{b} *}$ \\ ${ }^{a}$ Istituto Sperimentale per la Selvicoltura, viale S. Margherita, 80-52100 Arezzo, Italy \\ ${ }^{b}$ Laboratoire de biologie forestière associé Inra, faculté des sciences, BP 239, 54506 Vandœuvre-lès-Nancy cedex, France
}

(Received 9 April 1997; accepted 11 February 1999)

\begin{abstract}
Allozyme markers (11 loci, 32 alleles) have been used to estimate the genetic diversity within the unique surviving population of the relic species Abies nebrodensis. Results were analysed in comparison with a reference system composed of 16 Italian populations of $A$. alba and one representative provenance of $A$. cephalonica, A. equi-trojani, A. bornmuelleriana and $A$. nordmanniana. These investigations allowed us i) to show that alleles Idh-2a and Pgi-la have contributed to the differentiation of the $A$. nebrodensis population from those of the reference system, ii) to show that the genetic diversity within $A$. nebrodensis is similar to that of dynamic silver fir populations growing in analogous isolation and progressive drifting situations, while, simultaneously, a very high excess of homozygotes is detected, iii) to identify in situ three different zones which corresponded to the diversity core of the species, one site in recolonizing phase and one site in an extinction phase. The origin of this particular situation is discussed and silvicultural interventions to relaunch the dynamics of the species are suggested. (C) Inra/Elsevier, Paris.)
\end{abstract}

Abies nebrodensis / mediterranean firs / genetic diversity / allozymes

Résumé - Évaluation par analyse du polymorphisme alloenzymatique, de la diversité génétique au sein de l'espèce relique Abies nebrodensis (Lojac.) Mattei. Des marqueurs alloenzymatiques (11 loci, 32 allèles) ont été utilisés pour évaluer la diversité génétique au sein de la seule population existante de l'espèce relique $A$. nebrodensis. Les résultats, rapportés à un système de référence composé de 16 populations italiennes d'A. alba et d'une provenance représentative d'A. cephalonica, A. equi-trojani, $A$. bornmuelleriana et $A$. nordmanianna, ont permis, (i) de montrer que la fréquence des allèles Idh-2a et Idh-2b permet de différencier A. nebrodensis des populations du système de référence, (ii) de montrer que la diversité génétique à l'intérieur d'A. nebrodensis est comparable à celle des populations du système de référence présentant des situations d'isolement et de dérive génétique comparables, alors qu'en même temps on observe un fort excès d'homozygotes (iii) de mettre en évidence in situ trois zones différentes représentant respectivement, le noyau de diversité de l'espèce, un site de reconquête et un site en phase d'extinction. L'origine de cette situation particulière est discutée et des mesures de gestion susceptibles de favoriser la reprise de la dynamique de l'espèce sont proposées. (@) Inra/Elsevier, Paris.)

Abies nebrodensis / sapins méditerranéens / diversité génétique / allozymes

\section{Introduction}

Abies nebrodensis is an endemic species of Sicily [20, $22,26]$ represented by a single relic population of only 29 adult trees and about 20 small seedlings [30] growing on the Madonie range, south of the city of Cefalù (figure 1). This species is the southernmost fir in Italy and, together with the Peloponnesus Greek fir $(A$. Cephalonica), represents the southernmost expression of the genus Abies in Europe.

\footnotetext{
* Correspondence and reprints

favre@scbiol.u-nancy.fr
} 


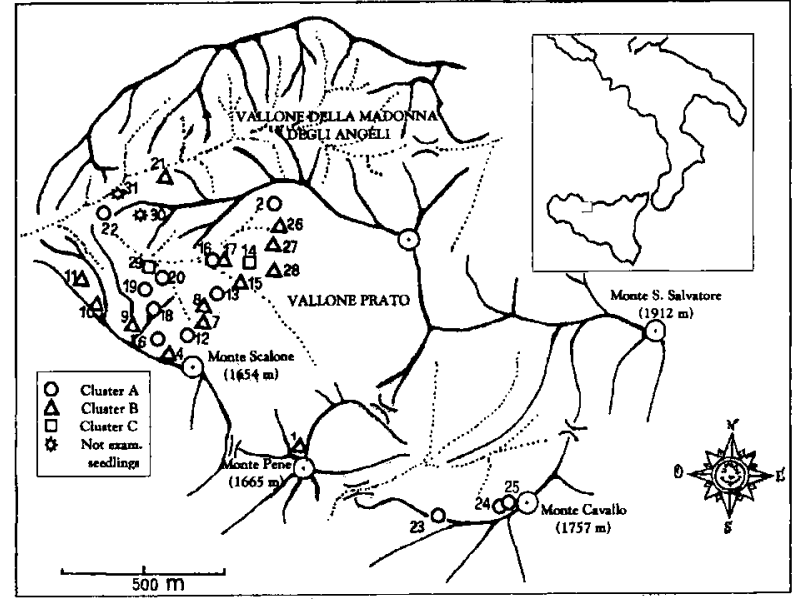

Figure 1. Natural range of A. nebrodensis in Sicily, Trees belonging to each similarity genetic cluster are shown with the same symbols.

The occurrence in the Madonie region of many endemic flora and fauna taxa testifies to the participation of $A$. nebrodensis in a former very ancient ecosystem, which is nowadays widely destroyed owing to intense human pressure $[3,37,39]$. However, the decline of the species seems to have occurred in relatively recent times. Indeed, it has been established that beams made from fir were still used in the XVIIth and XVIIIth centuries in roofing the churches of several villages (Polizzi Generosa, Petralia Sottana, Isnello) located within a $30-40-\mathrm{km}$ circle around the Madonie range [26]. This attests to the existence at the time of quite extensive fir forest resources including $A$. alba and $A$. nebrodensis populations as confirmed by Biondi and Raimondo [4].

At present, the Sicilian fir is considered as an endangered original gene pool [36] and several international organizations such as the Council of Europe [8], IUCN [18], FAO [28] mentioned A. nebrodensis in their red lists. Locally, action was taken to protect this germplasm following two directions: an in situ protection of trees was ensured by the establishment, within the Natural Park of Madonie, of a strict Reserve Area covering the A. nebrodensis population [10] and an ex situ conservation programme is being carried out by the Forest Research Institute of Arezzo [30].

After the first inventories made by Morandini in 1964 and $1968[26,27]$ and a field survey carried out in 1992 , an updated list of $A$. nebrodensis trees growing in the Madonie range was drawn up and, for each tree, topographical, morphological and phytoecological data were recorded $[30,37]$. Two clonal grafted collections including copies of 27 of the 29 compiled trees were established in 1992-1993 at the Forest Research Institute of Arezzo. Two trees were too small to endure scion removal without damage.

In this paper we investigated the genetic diversity within this material which represents an almost exhaustive collection of the species, using allozyme markers which have proved to be accurate in several genetic and phylogenetic studies on Abies species $[1,5,11,12,17$, $21,32,33,41,42,44]$. This information is essential to assess the genetic potential of the species in order to reestablish a biological dynamics and decide on appropriate conservatory actions.

A. nebrodensis was compared to a group of dynamic populations of silver fir ( $A$. alba) ranging from northern to southern Italy and one representative provenance of four fir species originating in the eastern Mediterranean region (A. nordmanniana, A. bornmuelleriana, A. equitrojani, A. cephalonica).

\section{Material and methods}

\subsection{Plant material}

The 29 Sicilian adult fir trees are distributed over an area of about 150 ha (figure 1).

This zone can be divided into four main sub-zones according to the site morphology and phytoecological parameters $[23,24,37]$.

1) The central sub-zone of the lower part of Vallone Prato is phytoecologically variable. Depending on orientation and altitude, the Sicilian fir trees occur in three situations:

- in the middle part (trees 18-20,29) beech (Fagion) with Luzula sicula is dominant;

- on the western side, Quercus petraea and Q. pubescens are present with Brachypodium sylvaticum and Juniperus hemispherica (trees 2, 14-17, 26-28);

- in the south-eastern part, fir trees (nos 7, 8, 12, 13) are scattered over a wide moving slope area.

2) The peripheral sub-zone of Vallone della Madonna degli Angeli which mainly includes northern-north-eastern slopes, belongs to the Quercion ilicis (trees: 21, 22, 30,31 ).

3) The peripheral sub-zone of Monte Cavallo which suffers from very hard site conditions can be connected with the Brachypodietalia phenicoides, but also includes truncated soils or lithosoils (trees: 23-25). 
4) The peripheral sub-zone of Monte Pene and Monte Scalone ridges characterized by very windy positions with exposure to the north-east, is covered by mixed patches of Geranio-versicoloris-Fagion and Cisto-ericetalia (trees: 1, 4, 6, 9-11);

Only 18 out of the 29 adult fir trees produce pollen and/or cones. For this reason we observed two distinctive populations in the analyses:

- Nebr 1, representing the total population of the 27 grafted trees;

- Nebr 2, representing that part of the population which is potentially capable of contributing to stand regeneration. This second population is composed of tree nos $1,2,6-13,17-23,27$.

Nebr 1 and Nebr 2 have been compared to a reference system composed of $16 \mathrm{~A}$. alba populations from Italy (several have been selected as seed stands by Morandini and Magini [29]) and one representative provenance [11, $12,25,41]$ of each of the following Mediterranean fir species: A. nordmanniana, A. bornmuelleriana, A. equitrojani and $A$. cephalonica (table I). All these populations have been described as dynamic, with good natural regeneration.

\subsection{Allozyme analysis}

Allozyme analysis was performed on samples of about $30-40$ buds per tree, collected during winter.

The sample extraction was carried out after centrifugation of the homogenated tissues for $10 \mathrm{~min}$ at 10000 $g$. The electrophoretic and staining procedures were performed according to Conkle et al. [7] and Santi [40]. Eight enzyme systems coded for by 12 loci were analysed: glutamic-dehydrogenase (Gdh, EC 1.4.1.2), glutamic-oxaloacetate-transaminase (Got, EC 2.6.1.1), isocitric-dehydrogenase (Idh, EC 1.1.1.42), leucineamino-peptidase (Lap, EC 3.4.11.1), malate-dehydrogenase (Mdh, EC 1.1.1.37), 6,posphogluconic-dehydrogenase (6,Pgdh, EC 1.1.1.44), phosphogluconic-isomerase (Pgi, EC 5.3.1.9) and shikimate-dehydrogenase (Skdh, EC 1.1.1.25). Due to insufficient availability of samples, this last enzyme system has only been analysed in the Nebr 1 and Nebr 2 populations.

The inheritance models of isozyme variants were described for Abies species by Schroeder [42], Bergmann et al. [1], Fady and Conkle [11], Pascual et al. [33], Hussendorfer et al. [17] and Longauer [21].

Table I. List of the examined populations and main geographical parameters.

\begin{tabular}{|c|c|c|c|c|c|c|}
\hline Species & Region & Population & $\begin{array}{l}\text { Mean altitude } \\
\text { (m) }\end{array}$ & $\begin{array}{l}\text { Latitude } \\
\left({ }^{\circ} \mathrm{N}\right)\end{array}$ & $\begin{array}{l}\text { Longitude } \\
\left({ }^{\circ} \mathrm{E}\right)\end{array}$ & $\begin{array}{c}\text { Number of trees } \\
\text { Examined }\end{array}$ \\
\hline A. nordmanniana & eastern Turkey & 1 Ardanug & 1925 & $41^{\circ} 34^{\prime}$ & $42^{\circ} 11^{\prime}$ & 36 \\
\hline A. equi-trojani & western Turkey & 3 Kazdag & 1280 & $39^{\circ} 50^{\prime}$ & $26^{\circ} 43^{\prime}$ & 36 \\
\hline A. cephalonica & southern Greece & 4 Vetyna & 1300 & $37^{\circ} 35^{\prime}$ & $22^{\circ} 15^{\prime}$ & 36 \\
\hline \multirow[t]{10}{*}{ A. alba } & Carnia & 5 Paularo & 1000 & $46^{\circ} 36^{\prime}$ & $12^{\circ} 38^{\prime}$ & 20 \\
\hline & & 8 Vallombrosa & 1000 & $43^{\circ} 49^{\prime}$ & $13^{\circ} 21^{\prime}$ & 36 \\
\hline & & 9 Camaldoli & 1100 & $43^{\circ} 48^{\prime}$ & $13^{\circ} 05^{\prime}$ & 36 \\
\hline & & 10 La Verna & 1000 & $43^{\circ} 44^{\prime}$ & $13^{\circ} 10^{\prime}$ & 29 \\
\hline & Molise & 11 Abeti Soprani & 1220 & $41^{\circ} 52^{\prime}$ & $14^{\circ} 17^{\prime}$ & 36 \\
\hline & Pollino Range & 12 San Francesco & 1500 & $39^{\circ} 54^{\prime}$ & $16^{\circ} 11^{\prime}$ & 36 \\
\hline & Sila Grande & 13 Macchia di Pietra & 1265 & $39^{\circ} 15^{\prime}$ & $16^{\circ} 19^{\prime}$ & 43 \\
\hline & Aspromonte & 18 Fossa Nardello & 1690 & $38^{\circ} 10^{\prime}$ & $15^{\circ} 47^{\prime}$ & 35 \\
\hline & & 19 Listì alto & 1560 & $38^{\circ} 10^{\prime}$ & $15^{\circ} 47^{\prime}$ & 36 \\
\hline & & 20 Listì basso & 1370 & $38^{\circ} 10^{\prime}$ & $15^{\circ} 47^{\prime}$ & 35 \\
\hline A. nebrodensis & Sicilia & 21 Madonie & 1865 & $38^{\circ} 50^{\prime}$ & $14^{\circ} 20^{\prime}$ & 27 \\
\hline
\end{tabular}




\subsection{Statistical analysis}

In order to assess genetic variation within the populations, the following parameters were used: allelic frequencies, mean number of alleles per locus, percentage of polymorphic loci, deviation from Hardy-Weinberg equilibrium, observed $(\mathrm{Ho})$ and expected $(\mathrm{He}$ ) heterozygosity and the fixation index (Fis), which were calculated using Biosys- $1[9,43]$.

The Levene's [43] correction for small size samples was used to carry out the Chi square test for deviation from the Hardy-Weinberg equilibrium.

For the analysis of the genetic variation within the Sicilian fir population, the genotype pattern of each tree was transformed into binary language (each allele at each locus was scored 1 for presence and 0 for absence). Data were then processed using the NTSYS statistic software [38] to carry out correspondence analysis and UPGMA clustering.

\subsection{Topographical distribution of the genotypes}

In order to visualize in situ the genetic differentiation within the A. nebrodensis population, the clusters established after the NTSYS analysis were plotted on the map, tree by tree.

\section{Results}

\subsection{Genetic variation within the populations of the Abies reference system}

The 11 loci analysed were polymorphic in at least one of the 20 reference populations. Thirty-two alleles were observed (table II). In A. alba, the mean number of alleles per locus estimated using pooled data without considering the population sub-divisions, was 2.8 (table III). Among the populations it ranged from 2.5 to 1.5 and the percentage of polymorphic loci varied from $36.4 \%$ (La Verna) to 90.9 \% (San Francesco, Santa Maria and Listì basso). Lowest values of these parameters were recorded in the northern Alpine provenances (Paularo and Chiusa Pesio).

Values for eastern fir species populations were globally similar, though varying within a narrower range.

The observed heterozygosity $(\mathrm{Ho})$ ranged from 0.108 to 0.248 in the $A$. alba reference populations and from 0.157 to 0.264 among the eastern Abies species. Positive values of estimated Fis in all populations (table III) indicated a general heterozygote deficiency within the reference system. The lower deficiencies were observed in the southern populations (Monte Pecoraro, Archiforo, Fossa Nardello, Listì alto).
Loci that deviated less frequently from HardyWeinberg equilibrium were Idh-2, 6,Pgd-2, Gdh-1, Pgi-1 and Pgi-2 (table IV). Idh-2, 6,Pgd-2 and Gdh-1 were characterized by an excess of heterozygosity among the examined $A$. alba populations.

\subsection{A. nebrodensis compared to the reference system}

Results of table III clearly show specific traits of genetic structure in the Nebr 1 population. Compared to the reference system, the mean number of alleles per locus, $\%$ of polymorphic loci and $\mathrm{Ho}$ were inferior. Higher value of $F i s$ indicated an increased heterozygote deficiency. These observations were particularly evident when Nebr 1 was referred to the $A$. alba pooled population. However, when the comparison was made individually with each of the 16 $A$. alba populations included in the reference system, some variations could be observed. The Nebr 1 mean number of alleles per locus and \% of polymorphic loci were very similar to that measured in the A. alba extensive populations of northern and central Italy (Chiusa Pesio, La Verna), while wider divergences were found with the southern populations (Fossa Nardello, San Francesco, Macchia di Pietra and Listì alto).

$H e$ was close to that of several A. alba populations (Chiusa Pesio, Abeti Soprani) and in some cases superior to northern (Paularo) or small and relatively isolated populations (La Verna, Gariglione). Neverthless, Ho in Nebr 1 was lower than in all the silver fir analysed populations.

Allele frequencies also showed Nebr 1-specific traits (table II). Idh-2a for instance exhibited a higher frequency in Nebr 1 than in the reference system while, conversely, Idh-2b was rare. A similar situation was observed for allele Pgi-1 a versus alleles Pgi-1b and c.

The number of rare or absent alleles in Nebr 1 (15) was higher than in the A. alba pooled population (9) although the wider sample size in this species. However, the number of absent alleles observed in the silver fir was about twice as high. Significant deviations from the Hardy-Weinberg equilibrium were found in five of the 11 examined alleles.

The main characteristics of the genetic structure observed in Nebr 1 were also found in the Nebr 2 restricted population. The observed differences concerned principally the percentage of polymorphic loci and the estimated $F i s$ which were inferior in Nebr 2 (table III). However, among the 11 analysed loci, seven exhibited slight excess of heterozygotes (table $I V$ ). Neverthless, the mean value of estimated $F$ is remained positive (table III). Results were similar for Skdh-2 (Fis: -0.048). 
Table II. Estimated allele frequencies for 11 allozyme loci (12 loci for A. nebrodensis) in the six examined fir species. Values for $A$. alba were estimated using pooled data without considering the population sub-divisions.

\begin{tabular}{|c|c|c|c|c|c|c|c|}
\hline Alleles & A. alba & $\begin{array}{c}\text { Abies } \\
\text { nordmanniana }\end{array}$ & $\begin{array}{c}\text { Abies } \\
\text { equi-trojani }\end{array}$ & $\begin{array}{c}\text { Abies } \\
\text { bornmuelleriana }\end{array}$ & $\begin{array}{c}\text { Abies } \\
\text { cephalonica }\end{array}$ & $\begin{array}{c}\text { Abies } \\
\text { nebrodensis } \\
\text { NEBR } 1\end{array}$ & $\begin{array}{c}\text { Abies } \\
\text { nebrodensis } \\
\text { NEBR } 2\end{array}$ \\
\hline \multicolumn{8}{|l|}{ Idh-2 } \\
\hline $\mathrm{a}$ & 0.595 & 0.074 & 0.280 & 0.391 & 0.556 & 0.981 & 0.972 \\
\hline b & 0.405 & 0.926 & 0.720 & 0.609 & 0.444 & 0.019 & 0.028 \\
\hline \multicolumn{8}{|l|}{6, PGD-1 } \\
\hline $\mathrm{a}$ & 0.282 & 0.185 & 0.087 & 0.125 & 0.355 & 0.463 & 0.500 \\
\hline b & 0.705 & 0.815 & 0.913 & 0.875 & 0.645 & 0.537 & 0.500 \\
\hline $\mathrm{c}$ & 0.013 & 0.0 & 0.0 & 0.0 & 0.0 & 0.0 & 0.0 \\
\hline \multicolumn{8}{|l|}{ 6,Pgd-2 } \\
\hline $\mathrm{a}$ & 0.917 & 1.0 & 0.978 & 1.0 & 0.891 & 0.907 & 0.972 \\
\hline b & 0.083 & 0.0 & 0.022 & 0.0 & 0.109 & 0.093 & 0.028 \\
\hline \multicolumn{8}{|l|}{ Gdh-1 } \\
\hline $\mathrm{a}$ & 0.070 & 0.019 & 0.080 & 0.033 & 0.016 & 0.0 & 0.0 \\
\hline b & 0.923 & 0.981 & 0.920 & 0.967 & 0.984 & 1.0 & 1.0 \\
\hline $\mathrm{c}$ & 0.007 & 0.0 & 0.0 & 0.0 & 0.0 & 0.0 & 0.0 \\
\hline \multicolumn{8}{|l|}{ Mdh-2 } \\
\hline $\mathrm{a}$ & 0.862 & 0.407 & 0.560 & 0.483 & 0.766 & 0.630 & 0.556 \\
\hline b & 0.138 & 0.556 & 0.440 & 0.500 & 0.234 & 0.370 & 0.444 \\
\hline c & 0.0 & 0.037 & 0.0 & 0.017 & 0.0 & 0.0 & 0.0 \\
\hline \multicolumn{8}{|l|}{ Lap-2 } \\
\hline $\mathrm{a}$ & 0.055 & 0.259 & 0.080 & 0.150 & 0.031 & 0.042 & 0.063 \\
\hline b & 0.865 & 0.741 & 0.840 & 0.800 & 0.844 & 0.792 & 0.937 \\
\hline c & 0.080 & 0.0 & 0.080 & 0.050 & 0.125 & 0.166 & 0.0 \\
\hline \multicolumn{8}{|l|}{ Pgi-1 } \\
\hline $\mathrm{a}$ & 0.109 & 0.0 & 0.0 & 0.0 & 0.0 & 0.778 & 0.778 \\
\hline b & 0.887 & 0.935 & 0.978 & 1.0 & 0.865 & 0.222 & 0.222 \\
\hline c & 0.004 & 0.065 & 0.022 & 0.0 & 0.135 & 0.0 & 0.0 \\
\hline \multicolumn{8}{|l|}{ Pgi-2 } \\
\hline $\mathrm{a}$ & 0.002 & 0.021 & 0.043 & 0.017 & 0.081 & 0.0 & 0.0 \\
\hline b & 0.010 & 0.0 & 0.0 & 0.0 & 0.0 & 0.037 & 0.028 \\
\hline c & 0.984 & 0.979 & 0.957 & 0.983 & 0.919 & 0.963 & 0.972 \\
\hline d & 0.004 & 0.0 & 0.0 & 0.0 & 0.0 & 0.0 & 0.0 \\
\hline \multicolumn{8}{|l|}{ Got-1 } \\
\hline a & 0.040 & 0.037 & 0.0 & 0.067 & 0.031 & 0.0 & 0.0 \\
\hline b & 0.920 & 0.963 & 1.0 & 0.867 & 0.969 & 1.0 & 1.0 \\
\hline c & 0.040 & 0.0 & 0.0 & 0.066 & 0.0 & 0.0 & 0.0 \\
\hline \multicolumn{8}{|l|}{ Got-2 } \\
\hline a & 0.135 & 0.037 & 0.083 & 0.0 & 0.266 & 0.111 & 0.028 \\
\hline b & 0.786 & 0.963 & 0.917 & 1.0 & 0.531 & 0.889 & 0.972 \\
\hline c & 0.079 & 0.0 & 0.0 & 0.0 & 0.203 & 0.0 & 0.0 \\
\hline \multicolumn{8}{|l|}{ Got-3 } \\
\hline $\mathrm{a}$ & 0.150 & 0.167 & 0.083 & 0.078 & 0.182 & 0.019 & 0.028 \\
\hline b & 0.793 & 0.722 & 0.875 & 0.766 & 0.636 & 0.981 & 0.972 \\
\hline c & 0.057 & 0.111 & 0.042 & 0.156 & 0.182 & 0.0 & 0.0 \\
\hline \multicolumn{8}{|l|}{ Skdh-2 } \\
\hline $\mathrm{a}$ & n.e. & n.e. & n.e. & n.e. & n.e. & 0.719 & 0.682 \\
\hline b & & & & & & 0.281 & 0.318 \\
\hline
\end{tabular}

n.e.: not examined. 
Table III. Genetic variation at 11 allozyme loci (12 loci for $A$ nebrodensis) in all the examined populations. Standard errors in brackets.

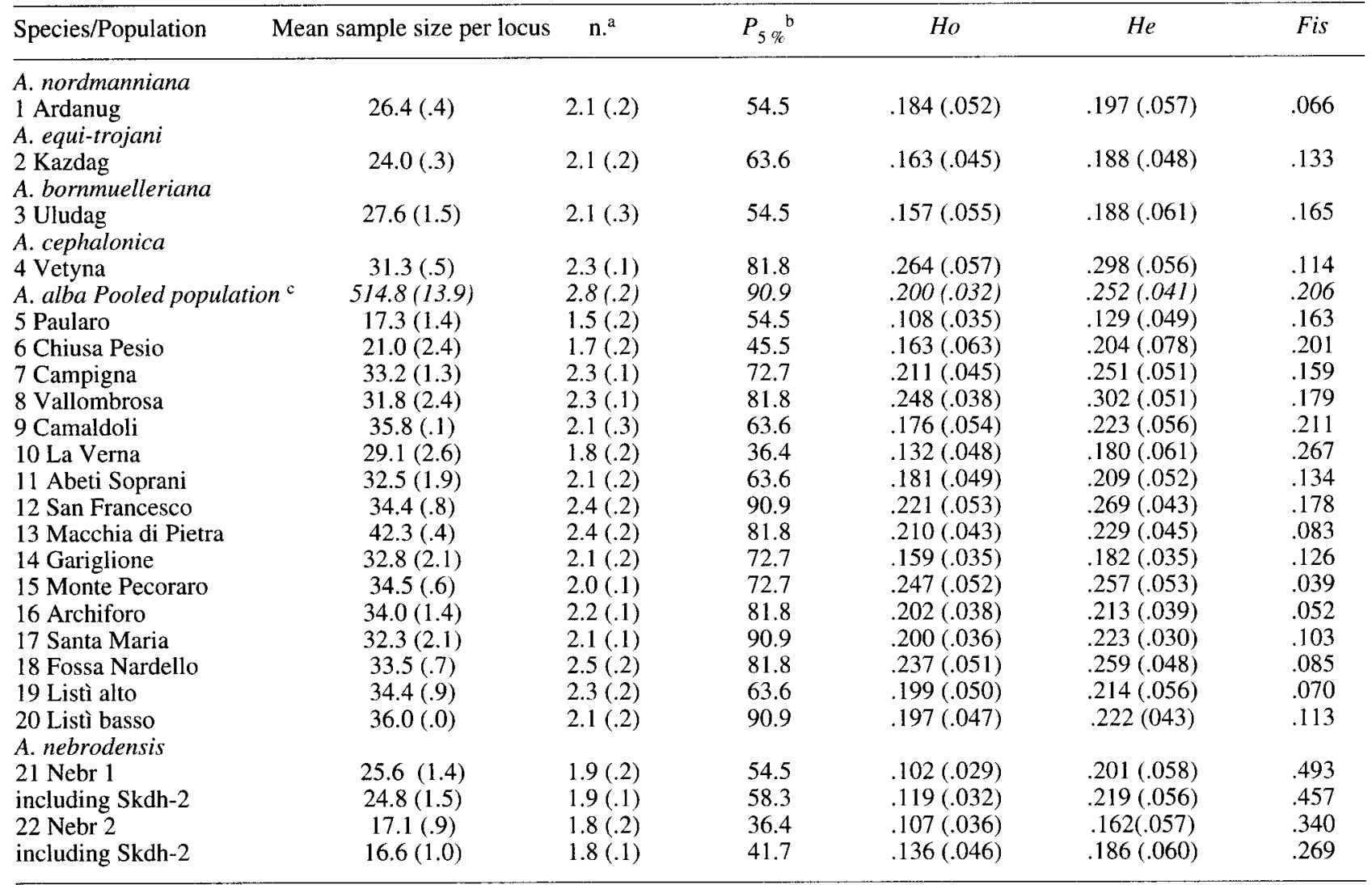

${ }^{a}$ Mean number of alleles per locus; ${ }^{b}$ percentage of polymorphic loci (a locus is considered polymorphic if more than one allele was detected); ${ }^{c}$ estimate using pooled data without considering population sub-divisions.

\subsection{Genetic differentiation within the $A$. nebrodensis population and in situ structuration of diversity}

The 27 A. nebrodensis trees showed different genotype in at least one locus. Seventy-three per cent of the total variance were explained by the first five factors of the correspondence analysis. Seven alleles were significantly correlated to these factors: Idh- $2 b, 6$,Pgd- $1 \mathrm{a}$ and $1 \mathrm{~b}$, Pgi-1b, Got-2a and $2 \mathrm{~b}$ and Got-3a.

The UPGMA dendrogram built using these alleles is given in figure 2. Taking into account the small size of the population, we accepted a differentiation into three main clusters. Cluster A included 12 trees (nos 2, 6, 12, $13,16,18-20,22-25$ ), cluster B grouped 13 trees (nos 1 , $4,7-11,15,17,21,26-28$ ) and cluster $C$, two trees (nos 14 and 29).

The Nebr 2 population was represented in clusters A and $\mathrm{B}$, each with $50 \%$ of total trees.
Trees of the different clusters were then plotted on the map (figure 1). It appeared that all of the three clusters were represented in the central sub-zone (bottom part of Vallone Prato). In contrast, in the peripheral sub-zones trees belonged to only one of the main clusters, namely cluster $\mathrm{A}$ in the peripheral sub-zone of Monte Cavallo, and cluster B in the peripheral sub-zone of Monte PeneMonte Scalone. Tree 6 on the Monte Scalone cresi was the unique exception.

The peripheral sub-zone of Vallone della Madonna degli Angeli was characterized by the presence of trees nos 21 and 22, belonging to clusters $A$ and $B$, respectively.

The in situ localization of the rare alleles identified in table II, confirmed this unequal distribution of the genotypes within the range of the species (table $V$ ). Indeed, all the rare alleles were located in the central sub-zone of Vallone Prato. 


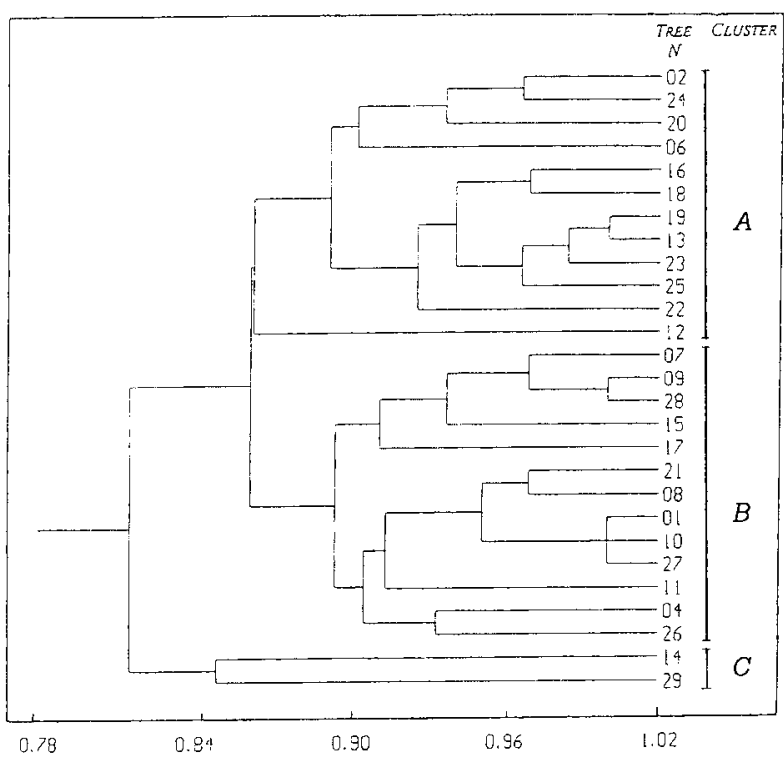

Figure 2. UPGMA dendrogram based on similarity matrix [38] obtained for all the examined trees.

\section{Discussion}

1) Many of the previous allozyme studies carried out on Abies species reported a deficiency of heterozygotes regardless of the examined enzyme loci, the number of analysed populations or the sample size. This was shown in several populations of $A$. alba as well as in other Mediterranean fir species such as $A$. cephalonica, $A$. equi-trojani, $A$. bornmuelleriana and $A$. borisii regis [1, $10,11,21,32,41,42,44]$. In $A$. alba for instance, estimated $F i s$ values ranging from 0.140 to 0.280 have been reported [44: northern Italian populations] indicating clear excess of homozygotes. However, in some populations, lower $F i s$ values showing no significant differences from the Hardy-Weinberg equilibrium have been observed. This is notably the case of the Calabrian population of Serra San Bruno in which the reported Fis values range from -0.080 [44] to 0.050 [32]. For a given population, differences among authors could be high. In Abeti Soprani (central Apennines) for instance, Fis values ranged from 0.050 [44] to 0.188 (calculated from Parducci et al. [32]), but the analysed loci, the revealed alleles and the number of sampled trees were different.

The results obtained in this study confirmed the general trend to heterozygote deficiency observed in Abies species, especially when referring to small and isolated stands. The occurrence of self pollination in Abies species [11, 41], confirmed in A. alba [13,32], together with the Walhund effect resulting from the ancient fractioning of the natural range of Abies around the Mediterranean basin, have probably contributed to the maintenance, such high homozygosity levels. The artificial origin of the A. alba Tuscan populations can also have determined higher deficiency of heterozygotes than in the natural populations of this species.

In addition to low heterozygosity, some authors ([1] and to some extent, [44]) confirmed by Parducci et al. [32] also observed an increasing variation in genetic parameters from the northern Alpine to the southern Italian A. alba populations. Our results also confirmed such a clinal northern-southern gradient within the Italian range of this species, more evidently when the artificial populations of Camaldoli, Campigna and Vallombrosa were excluded.

In conclusion, the overall consistency of our results with the previously collected data, also evident for genetic parameters such as the number of alleles per locus, percentage of polymorphic loci and $\mathrm{He}$, shows that the $16 \mathrm{~A}$. alba and four eastern fir species populations analysed can be considered as representative of the general situation in the Mediterranean Abies species, and thus validates the choice of these populations as a reference system in assessing the genetic diversity within $A$. nebrodensis.

2) In a general way, the genetic diversity within both the Nebr 1 and Nebr 2 populations was lower than in the reference system. However, a detailed examination of the main genetic parameters showed similarities with several A. alba populations (Paularo, Chiusa Pesio, La Verna and Gariglione) which share with $A$. nebrodensis common traits such as ecological conditions, altitudinal and/or geographical position, long time isolation and progressive reduction in tree density.

The northern geographic position, where genetic diversity is known to be low [1] and exposure to extreme climatic conditions owing to altitude and relative isolation for instance, can explain the results obtained in Paularo and Chiusa Pesio, respectively. The isolating effects of altitude and local topography can also account for the similarity of genetic parameters in the small-sized population of La Verna and A. nebrodensis. The case of the wider population of Gariglione which surprisingly showed lower genetic diversity $(\mathrm{He})$ than $\mathrm{A}$. nebrodensis and all the other analysed Calabrian populations, could be considered as a result of long time geographic isolation as already indicated by Parducci et al. [32].

A. nebrodensis collects together the specific traits of these four geographically distant dynamic A. alba populations of the reference system: geographic and topo- 
Table IV. Mean fixation index (Fis) and probability of deviation from Hardy-Weinberg equilibrium estimated using $\chi^{2}$ test between observed and expected alleles frequencies at polymorphic loci (* indicates significant deviation at $P=0.05$ ).

\begin{tabular}{|c|c|c|c|c|c|c|c|c|c|c|c|}
\hline Species/Population & $\begin{array}{l}\text { Locus } \\
\text { IDH-2 }\end{array}$ & 6Pgd-1 & $6 \mathrm{Pgd}-2$ & Gdh-1 & Mdh-2 & Lap-2 & Pgi-1 & Pgi-2 & Got-1 & Got-2 & Got-3 \\
\hline $\begin{array}{l}\text { A. nordmanniana } \\
\text { I Ardanung }\end{array}$ & -.080 & .264 & $\mathrm{~m}$ & -.019 & .010 & $.036 *$ & -.070 & -.021 & -.038 & $-.038^{*}$ & .070 \\
\hline $\begin{array}{l}\text { A. equi-trojani } \\
2 \text { Kazdag } \\
\text { A. bornmuelleriana }\end{array}$ & -.190 & $-.095^{*}$ & -.022 & -.087 & .188 & $.432 *$ & -.022 &.- .045 & $\mathrm{~m}$ & $.455^{*}$ & .262 \\
\hline $\begin{array}{l}3 \text { Uludag } \\
\text { A. cephalonica }\end{array}$ & -.053 & $.429 *$ & $-.034 *$ & $\mathrm{~m}$ & -.096 & .104 & $\mathrm{~m}$ & -.017 & $.444^{*}$ & $\mathrm{~m}$ & .044 \\
\hline $\begin{array}{l}4 \text { Vetyna } \\
\text { A. alba }\end{array}$ & .015 & -.127 & -.123 & -.016 & .042 & $.770^{*}$ & .175 & $.347^{*}$ & -.032 & $.175^{*}$ & -.060 \\
\hline Pooled population ${ }^{a}$ & $.177 *$ & $.249 *$ & .057 & $.155^{*}$ & $.101^{*}$ & $.183^{*}$ & $.289 *$ & $.226 *$ & $.178^{*}$ & $.257^{*}$ & $.271 *$ \\
\hline 5 Paularo & -.091 & .367 & $\mathrm{~m}$ & .297 & -.056 & $\mathrm{~m}$ & $\mathrm{~m}$ & $\mathrm{~m}$ & $\mathrm{~m}$ & -.086 & -.152 \\
\hline 6 Chiusa Pesio & $.406^{*}$ & .067 & -.021 & $\mathrm{~m}$ & .064 & $\mathrm{~m}$ & $\mathrm{~m}$ & $\mathrm{~m}$ & $\mathrm{~m}$ & -.083 & .316 \\
\hline 7 Campigna & .153 & .022 & -.031 & $.471^{*}$ & $.354 *$ & $.171^{*}$ & -.043 & -.029 & .107 & $.222 *$ & .152 \\
\hline 8 Vallombrosa & .010 & .159 & .196 & -.180 & .291 & .164 & -.043 & -.014 & -.043 & .232 & .313 \\
\hline 9 Camaldoli & -.277 & .167 & -.043 & $\mathrm{~m}$ & -.094 & $.237 *$ & $\mathrm{~m}$ & $\mathrm{~m}$ & $.450^{*}$ & $.786^{*}$ & .172 \\
\hline 10 La Verna & -.097 & .187 & -.016 & .318 & $-.049 *$ & $\mathrm{~m}$ & $\mathbf{m}$ & $\mathrm{m}$ & $.650^{*}$ & $1.00^{*}$ & $.434 *$ \\
\hline 11 Abeti Soprani & .134 & -.011 & .195 & -.014 & $.355^{*}$ & $1.00^{*}$ & m & $\mathrm{m}$ & -.118 & .030 & .227 \\
\hline 12 San Francesco & $-.412 *$ & .163 & .044 & .074 & .209 & .176 & -.085 & $\mathrm{~m}$ & $.106^{*}$ & $.825 *$ & $.718^{*}$ \\
\hline 13 Macchia di Pietra & .184 & .048 & -.111 & .236 & -.099 & -.057 & -.024 & $\mathrm{~m}$ & $.264^{*}$ & .070 & .187 \\
\hline 14 Gariglione & .150 & .067 & -.077 & -.029 & .103 & -.094 & -.099 & $\mathrm{~m}$ & -.029 & .067 & $1.00 *$ \\
\hline 15 Monte Pecoraro & -.042 & -.014 & -.167 & -.043 & .153 & -.074 & .291 & $\mathrm{~m}$ & -.030 & .014 & .051 \\
\hline 16 Archiforo & .0001 & -.001 & .156 & -.029 & -.125 & -.107 & -.075 & -.043 & -.056 & .121 & .447 \\
\hline 17 Santa Maria & -.125 & $.438 *$ &.-108 & -.091 & -.108 & .270 & .156 & -.043 & $.636^{*}$ & -.113 & .179 \\
\hline 18 Fossa Nardello & -.202 & .264 & -.048 & -.061 & .006 & .072 & .150 & $.449 *$ & -.034 & $.355^{*}$ & $.040^{*}$ \\
\hline 19 Listì alto & .0001 & $.351^{*}$ & -.043 & -.059 & -.043 & .129 & .026 & $\mathrm{~m}$ & -.029 & .113 & -.110 \\
\hline 20 Listì basso & -.155 & .156 & -.091 & -.059 & -.037 & -.125 & $1.00^{*}$ & $\mathrm{~m}$ & -.079 & .056 & -.059 \\
\hline $\begin{array}{l}\text { A. nebrodensis } \\
21 \text { Nebr } 1\end{array}$ & & & & & & & & & & & \\
\hline $\begin{array}{l}21 \text { Nebr } 1 \\
22 \text { Nebr } 2\end{array}$ & $\begin{array}{l}-.019 \\
-.029\end{array}$ & $.778^{*}$ & $\begin{array}{l}-.102 \\
-.029\end{array}$ & $\begin{array}{l}\mathrm{m} \\
\mathrm{m}\end{array}$ & $\begin{array}{l}.365^{*} \\
.100\end{array}$ & $\begin{array}{l}-150 \\
-.067\end{array}$ & .357 & $\begin{array}{l}-.038 \\
-.029\end{array}$ & $\begin{array}{c}\mathrm{m} \\
-.029\end{array}$ & $\begin{array}{l}.025^{+} \\
-.029\end{array}$ & $\begin{array}{l}-.019 \\
-.048\end{array}$ \\
\hline
\end{tabular}

"Estimate using pooled data without considering population sub-divisions. $\mathrm{m}$ : monomorphic locus in the population.

graphic isolation, extreme climatic and edaphic growth conditions, anthropic pressure, and a dramatically reduced number of trees. The main difference concerned the genetic structure, characterized by a really high excess of homozygotes. Fis values recorded in both the Nebr 1 and Nebr 2 populations were about twice as high as in the pooled $A$. alba reference population and even more in the Paularo, Chiusa Pesio, La Verna and Gariglione populations.

These very high values of Fis could be attributed to several causes probably joint in their results, i.e. too great a distance between the trees, increased rate of self pollination due to high scattering of the trees, genetic drift, stochastic selection effect of position of the living trees and of their earlier parent trees $[14,15]$.

In contrast with the estimated Fis the other genetic parameters (especially the number of alleles per locus, percentage of polymorphic loci and $\mathrm{He}$ ) exhibited close values in the Nebr 1 and Nebr 2 populations compared to the four comparable A. alba populations of the reference system. This suggests that despite the relic conditions and very small size of population (27 trees), A. nebrodensis still retains a representative sampling of the genetic potential of the former tree generations, when the stand was more extended. The fact that the allele pattern found in Nebr 1 and in Nebr 2 was relatively similar to those of populations of other species confirmed this conclusion. Indeed, among the 32 alleles detected within 11 enzyme systems only two (Idh-2a versus Idh-2b and Pgi1 a versus Pgi-1b) turned to higher or lower frequency in A. nebrodensis, whereas they were conversely rare or frequent in the reference system.

The case of locus Idh-2 was especially interesting to consider. Frequency of allele Idh-2a was two to ten times higher in $A$. nebrodensis than in the A. alba, A. cephalonica and $A$. nordmanniana populations. Bergman 
Table V. Repartition of $A$. nebrodensis rare (frequency < 0.05 ) and fairly rare (frequency $0.1 \sim 0.05$ ) alleles among the clusters and distribution within the geographical sub-zones.

\begin{tabular}{lccccc}
\hline $\begin{array}{l}\text { Rare } \\
\text { allele }\end{array}$ & $\begin{array}{c}\text { Frequency } \\
\text { within } \\
\text { Nebr 1 }\end{array}$ & $\begin{array}{c}\text { Frequency } \\
\text { within } \\
\text { Nebr } 2\end{array}$ & $\begin{array}{c}\text { Tree } \\
\text { Nebster } \\
\text { no. }\end{array}$ & $\begin{array}{l}\text { Sub- } \\
\text { zone }\end{array}$ \\
\hline Idh-2b & 0.019 & 0.028 & $12^{*}$ & A & Vallone Prato \\
6,Pgd-2b & 0.093 & 0.028 & 4 & B & Monte Pene \\
& & & $11^{*}$ & B & Monte Pene \\
& & & 14 & C & Vallone Prato \\
& & & 16 & A & Vallone Prato \\
Lap-2b & 0.042 & 0.063 & 26 & B & Vallone Prato \\
Pgi-2b & 0.037 & 0.028 & 15 & A & Vallone Prato \\
& & & $20^{*}$ & A & Vallone Prato \\
Got-2a & 0.111 & 0.028 & 4 & B & Monte Prato \\
& & & 14 & C & Vallone Prato \\
& & & $22^{*}$ & B & Vallone M. Angeli \\
& & & 29 & C & Vallone Prato \\
Got-3a & 0.019 & 0.028 & $17^{*}$ & B & Vallone Prato \\
\hline
\end{tabular}

* Trees helonging to both the Nebr 1 and Nebr 2 populations.

and Gregorius [2] studying 45 European populations of $A$. alba including six from Calabria, showed inverse variation from north to south of Idh-2a and Idh-2b frequencies, the former being lowest in the south. They interpreted this result as a consequence of a lower thermostability of this allele. Thus, the maintenance within A. nebrodensis of a high frequency of Idh-2a (present in all trees but one) could be due to the cold climatic conditions (altitude, northern slopes) of the Madonie site, which reduce the selection against this negatively thermo-influenced allele. The same explanation can be given to account for the results of Longauer [21] who also found high Idh-2a frequencies $(0.70)$ in Calabrian populations of $A$. alba close to $A$. nebrodensis.

Finally, compared to the reference system, the relic population of $A$. nebrodensis appeared to be characterized by both relatively normal genetic diversity (i.e. number of alleles per locus, number of polymorphic loci, expected heterozygosity) and increased deficiency of heterozygotes. According to Gregorius and Bergmann [14] the higher frequency of some alleles, as well as homozygosity, could be explained by the adaptation to peculiar local environmental conditions, indicating thus that the genetic diversity within $A$. nebrodensis is compatible with a possible restoring of dynamics in the population.

3) The in situ identification of trees according to the UPGMA clustering of the $A$. nebrodensis population showed a heterogeneous distribution of genetic variation in connection with the high microenvironmental diversi- ty of the species area. Such an explicative relationship between genetic variation and microenvironmental diversity has also been suggested by Müller-Starck [31] for altitude Alpine spruce stands.

Within the Sicilian fir range, three different situations can be described. On both the southern peripheral crest zones of Monte Cavallo and Monte Pene-Monte Scalone, which are subjected to extreme environmental conditions, especially freezing cold winds, trees belonged to only one of the three identified clusters. The future long-term survival of these trees is doubtful, and although some seedlings are present around tree 1 on the Monte Pene summit, an efficient recolonizing process is very unlikely. These sites can be therefore considered as in an extinction phase.

The situation in the central zone of Vallone Prato is quite different. The three genotype clusters, as well as the five rare alleles observed, were represented among the trees present on this site. Vallone Prato can be thus considered as the diversity core of the population, containing the main part of the gene pool and hence constitutes the priority zone for in situ conservation.

It is important, however, to note that this central zone also conceals high microenvironmental and phytoecological diversity which can represent, on the one hand suitable conditions to maintain genetic diversity, but on the other adverse conditions for natural regeneration and population increase. Along the upper limits of the Vallone, as on the surrounding ridges of Monte Scalone, trees are exposed to drastic edaphic conditions (deep intensively eroded rocky slopes) which are unsuitable for regeneration. In lower locations the soil conditions are better, but trees are subjected to increasing beech coppice competition. The evolution of the beech coppice into high forest formation was predicted as early as 1960 by Hoffmann [16] and recently confirmed by Raimondo et al. [37]. The environmental conditions, especially the light conditions, created by the expansion of the coppice, today aged 40-45 years [16] are unsuitable for cone production, germination and development of the fir seedlings. In some cases the fir trees are in danger of being surpassed by the coppice. Examples of such a regression and sometimes complete substitution of Abies by beech have been observed in several Calabrian forests [6].

This evolution within the diversity core of the population poses a threat to the future of the fir trees. Silvicultural interventions should be rapidly realized in order to stimulate the fir reproductive maturation and regeneration. Selective thinning of the beech coppice, for instance, would open patches favourable to seed germination and growth of seedlings, relaunching the dynamics of the fir population as recommended by Ciancio et 
al. [6] and Lovino and Menguzzato [19] to preserve the A. alba populations of the Calabrian forest.

The northern zone of Vallone della Madonna degli Angeli harbours the only two adult trees at present able to regenerate living seedlings with wide survival potential (trees 21 and 22). They represent the unique part of the population which can be considered in expansion. They belong to clusters A and B, respectively. Tree 22 possess the Got-2a rare allele. These trees possibly derive from Vallone Prato and find in this new site favourable ecological conditions. Indeed, in the opening of this small valley, phytoecological conditions are different from those of Vallone Prato. As in the typical Mediterranean oak/fir succession [34, 35], A. nebrodensis is associated there with Quercus ilex and a mixture of mountain and sub-mountain harwoods and shrubs such as Fraxinus ornus, Arbutus unedo, Ilex aquifolium, Acer campestre, etc. $[16,26]$ and finds appropriate conditions to re-start an expansion phase.

Therefore, in contrast with Vallone Prato, any sylvicultural intervention should be avoided in this zone. Only the establishment of small diffusion cores composed of propagation material issued from the three clusters could possibly be considered. Special interest could also be given to the diffusion of seedlings born from rare allele carrier mother trees.

In this way, the genetic diversity patterns within this potential expansion zone of the species could be improved.

Acknowledgements: This work has been partially funded by the Italian-French framework of scientific cooperation 'Galileus' and by the EC research programme 'Mediterranean Firs and Cedars'. The authors wish to thank Professor Riccardo Morandini, former Director of the Forest Research Institute of Arezzo, for his comments and suggestions.

\section{References}

[1] Bergmann F., Larsen J.B., Gregorius H.R., Genetische Variation in verschiedenen Arealen der Weisstanne Abies alba Mill., Erhaltung forstlicher Genressources, Schrift. a d Forstl. Fak., Goettingen 98 (1990) 130-140.

[2] Bergmann F., Gregorius H.R., Ecogeographical distribution and thermostability of Isocitrate dehydrogenase (IDH) in European Silver fir (Abies alba), Biochem. Syst. Ecol. 21 (1992) 597-605.

[3] Binazzi A., Covassi M., Il genere Dreyfusia Boerner in Italia con la descrizione di una specie nuova (Homoptera Adelgidae), Redia 74 (1991) 233-299.

[4] Biondi E., Raimondo F.M., Primo rinvenimento di legni fossili sulle Madonie, Giorn. Bot. It. 114 (1980) 128-129.
[5] Breitenbach-Dorfer M., Mueller F., Pinsker W., Hacker R., Allozyme variation in populations of Abies alba from six regions of Austria, in: Baradat Ph., Adams W.T., Muller-Starck G. (Eds.), Population Genetics and Genetic Conservation of Forest Trees, Academic Publishers, Amsterdam, 1995, pp. $237-245$.

[6] Ciancio O., Iovino F., Menguzzato G., Mirabella A., L'abete (Abies alba Mill) in Calabria, Ann. Ist. Sper. Selv., Arezzo, 16 (1985) 7-249.

[7] Conkle M.T., Hodgkiss P.D., Nunnally L.B., Hunter S.C., Starch gel electrophoresis of Conifer seeds: a laboratory manual, USDA FS Gen. Tech. Rep. PSW-64, 1982.

[8] Conseil de l'Europe, Liste des plantes rares, menacées et endémiques en Europe, Collection Sauvegarde de la Nature, Strasbourg, 1977.

[9] El Kassaby Y.A., Genetic variation within and among Conifer populations: review and evaluation of methods, in: Fineschi S., Malvolti M.E., Cannata F., Hattemer H.H. (Eds.), Biochemical markers in the population genetics of forest trees, Academic Publishers, the Hague, 1991, pp 61-76.

[10] Ente Parco Madonie, Nel Parco, Ettore Magno, Palermo 1992, $61 \mathrm{p}$.

[11] Fady B., Conkle M.T., Segregation and linkage of allozymes in seed tissues of the hybrid Greek Fir Abies borisii regis Mattfeld, Silvae Genet. 41 (1992) 273-278.

[12] Fady B., Conkle M.T., Allozyme variation and possible phylogenetic implications in Abies cephalonica Loudon and some related Eastern Mediterranean Firs, Silvae Genet. 42 (1993) 351-359.

[13] Gellini R., (1977) Il genere Abies, in: Botanica Forestale, Clusf., Firenze, t. II, 1977, pp. 41-58.

[14] Gregorius H.R., Bergmann F., Analysis of isozyme genetic profiles observed in forest tree populations, in: Baradat Ph., Adams W. T., M, ller-Starck G. (Eds.), Population Genetics and Genetic Conservation of Forest Trees, Academic Publishers, Amsterdam, 1995, pp. 79-96.

[14] Hamrick J.L., Plant population genetics and evolution, Am. J. Bot. 69 (1982) 1685-1693.

[15] Hamrick J.L., Isozymes and the analysis of genetic structure in plant populations, in: Soltis D.E., Soltis P.S. (Eds.), Isozymes in Plant Biology, Dioscorides Press, Portland, 1989, pp. 87-105.

[16] Hoffmann A., Il faggio in Sicilia, in: Monografie sulla flora e vegetazione d'Italia, Gianasso, Palermo, 1960, pp. 9-235.

[17] Hussendorfer E., Konnert M., Bergmann F., Inheritance and linkage of isozyme variants of silver fir (Abies alba Mill), For. Genet. 2 (1995) 29-40.

[18] IUCN, The IUCN Plant Red Data Book, Lucas \& Synge, Morges, 1978.

[19] Iovino F., Menguzzato G., L'abete bianco sull' Appennino lucano, Ann. Accad. It. Sci. For., Firenze 42 (1993) 185-214.

[20] Lojacono Poiero M., Flora sicula, Palermo, 1907. 
[21] Longauer R., Genetic diversity of European Silver Fir (Abies alba Mill), Doctoral thesis, Technickà Universzita Zvolene, Zvolen, 1996, 154 p.

[22] Mattei G. E., L'Abete dei Nebrodi, Boll. R. Orto. Bot. Giard. Col., Palermo 7 (1908) 56-59.

[23] Martino A.D., Marceno C., Raimondo F.M., Nota preliminare sulla vegetazione gipsofila della Sicilia centro-meridionale, Giorn. Bot. It. 111 (1977) 369-370.

[24] Martino A.D., Marceno C., Raimondo F.M., Sintesi degli studi condotti sulla vegetazione delle Madonie, Giorn. Bot. It. 111 ( 1977) 370-371.

[25] Mitsopulos D.J., Panetsos C.P., Origin of variation in Fir forests of Greece, Silvae Genet. 36 (1987) 1-15.

[26] Morandini R., Abies nebrodensis (Lojac) Mattei, Inventario, 1968. Pubblicazione no. 18, Ist. Sper. Selv., Arezzo, 1969,93 p.

[27] Morandini R., Per la protezione dell' abete in Sicilia, in: La Sezione Fiorentina del CAl-1868-1968, Firenze, 1969, pp. 411-414.

[28] Morandini R., Abies nebrodensis (Lojac.) Mattei, in: FAO, Databook of Endangered Tree and Shrub Species and Provenances, FAO forestry paper no. 77, 1986, pp. 11-20.

[29] Morandini R., Magini E., Il materiale forestale di propagazione in Italia, in: Min. Agr. For. Corpo Forestale dello Stato (Ed.), Collana Verde, Rome, vol. 34, 1975, pp. 162-169.

[30] Morandini R., Ducci F., Menguzzato G., Abies nebrodensis (Lojac) Mattei-Inventario 1992, Ann. Ist. Sper. Selv., Arezzo 22 (1994) 5-51.

[31] Müller-Starck G., Genetic variation under extreme environmental conditions, in: Baradat Ph., Adams W. T., Müller-Starck G. (Eds.), Population Genetics and Genetic Conservation of Forest Trees, Academic Publishers, Amsterdam, 1995, pp. 201-210.

[32] Parducci L., Szmidt A.E., Wang X.R., Cherubini M., Genetic variation of Abies alba in Italy, Hereditas 125 (1996) 11-18.

[33] Pascual L., Garcia F.J., Perfectti F., Inheritance of Isozyme Variations in seed Tissues of Abies pinsapo Boiss., Silvae Genet. 42 (1993) 335-340.

[34] Quezel P., Biogeography and ecology of conifers in the Mediterranean area, in: Pesson P. (Ed.), Recent Research in
Forest Ecology. Soils, Flora, Fauna, Gauthier-Villars, Paris, 1980 , pp. 205-255.

[35] Quezel P., Barbero M., Caracteristiques écologiques, dynamiques et structurales des populations naturelles de sapins sur le pourtour mediterranéen, in: Ducrey M., Oswald $\mathrm{H}$. (Eds.), Proceedings of International EEC workshop on Mediterranean Firs, Avignon, 1991, pp. 23-25.

[36] Raimondo F.M., Giancuzzi L., Ilardi V., Inventario delle specie "a rischio" nella flora vascolare nativa della Sicilia, Quad. Bot. Ambientale, Palermo 3 (1992) 65-132.

[37] Raimondo F.M., Giancuzzi L., Schicchi R., Carta della vegetazione del massiccio carbonatico delle Madonie (Sicilia centro - settentrionale), Quad. Bot. Ambientale, Palermo 3 (1992) 23-40.

[38] Rohlf J.F., NTSYS, Numerical Taxonomy and Multivariate Analysis System, Version 180, Exeter Software, New York, 1994.

[39] Rovelli E., La distribuzione dell'abete (Abies alba Mill) sull' Appennino, Monti e Boschi, Bologna 6 (1995) 5-13.

[40] Santi F., Variabilité génétique inter- et intrapopulations chez le merisier (Prunus avium L.), thesis, INA Paris-Grignon, 1988, 94 p.

[41] Scaltsoyiannes A., Panetsos K.P., Zaragotas D., Genetic variation of greek fir as determined by isozyme analysis and its relation to other mediterranean firs, in: Ducrey M., Oswald H. (Eds.), Proceedings of International EEC workshop on Mediterranean Firs, Avignon, 1991, pp. 99-115.

[42] Schroeder S., Die Isoenzym-Variation der Weißtanne (Abies alba Mill) in 16 europäischer Provenienzen, Mitt. Verein. Forstl. Standortskunde u Forstpflanzenzüchtung 34 (1989) 77-81.

[43] Swofford D.L., Selander R.B., Biosys-1, Release 1.7. A computer Program for the Analysis of Allelic Variation in Population Genetics and Biochemical Systematics, Swofford D. L., Champaign, Illinois, 1989.

[44] Vicario F., Vendramin G.G., Rossi P., Liò P., Giannini R., Allozyme, chloroplast DNA and RAPD markers for determining genetic relationships between Abies alba and the relic population of A. nebrodensis, Theor. Appl. Genet. 90 (1995) 1012-1018. 